\title{
DEVELOPMENT OF A CONCEPTUAL APPROACH TO PROVIDING ECONOMIC SECURITY OF BANKING INSTITUTIONS AT THE STATE LEVEL
}

\author{
Yana Koval \\ PhD (Public administration), associate professor, "KROK” University, e-mail.: koval_y.s@ukr.net, \\ ORCID: https://orcid.org/0000-0001-6578-2996
}

\begin{abstract}
Over the twenty years of Ukraine's independence, the category of "bank" has evolved from a purely institutional economic category into a socio-political category, and in the face of the financial crisis, a litmus test to determine the stability of Ukraine's sociopolitical and economic independence. Recall that the main essence of the bank, its basis is the organization of the monetary process and the imitation of banknotes. Unfortunately, in times of political instability, the banking system has evolved from a financial transformation tool to a tool of social influence and social conflict. A strong financial system can only be provided that it relies on self-sufficient, scientifically capacious, competitive own production. According to the criteria of American economic science, we have the collapse of the monetary system, because, first, people's savings are not transformed into investments and, secondly, our banking system does not credit our own production. Therefore, in order to create a market economic system in Ukraine, it is necessary to solve the problem of creating a banking system that reflects the interests of Ukraine and not the interests of the countries of elitism - in conquering the Ukrainian market and its financial enslavement, which is much more important and more complex than the solution, for example total privatization. Reforms in Ukraine emphasize that the formation of new approaches to socio-economic transformation should be based both on the results of scientific analysis of their own trajectory of development and on generalizing global trends, including understanding the nature of the current global crisis. The world is entering a new era, characterized by a significant increase in the unpredictability and uncertainty of development, when different crises will constantly arise and disappear in different local areas of the world economy, periodically joining chains and forming a global crisis. In these global fluctuations, only social development that relies on a competitive economy can be sustainable; developed domestic market; a national manufacturing facility that fully exploits the potential of transnational capital and guarantees the country's economic security; a balanced social structure and an effective political system.
\end{abstract}

Keywords: economic security, banking institutions, government mechanism, concept, innovation system.

JEL Classification: M10, M11, M21, H79, P35, E69

Formulas: 0; fig.: 0; tabl.: 0; bibl.: 10 .

Introduction. In legal science, state regulation is the implementation by the state of complex measures (organizational, legal, economic, etc.) in the field of social, economic, political spiritual and other processes in order to streamline them, to establish general rules and norms of social behavior, as well as to prevent negative phenomena in society . The essence of state regulation of the banking sector of Ukraine is manifested through the exercise of functions entrusted to it by the society and the state of the financial sector of the state. Given the important place of the banking system in the economy of the country, the high level of dependence of economic and global security on its status, the organization of state regulation, functioning and development of the banking system of Ukraine is of paramount importance. The adequacy of the state 
regulation system to fulfill the functions of coordination in the activity of financial and credit institutions will depend on the development of the Ukrainian economy and the further economic growth of the financial and credit sector of the economy.

Literature review. Analysis of the publications of such authors as Bolgar T.M., Vashchenko N.V., Hrytsenko R., Donetsk L.I., Dmitrov S.O., Duhov V.E., Zubok M.I., Zachosova N. V., Medvid T.A., Mihus I. P., Poberezhny S.M., Plastun O.L., Sumets L.M., Tumar M.B., Khudoliy L.M. showed that despite the large number of works by Ukrainian and foreign scientists, the only approach to providing economic security of state-owned banking institutions.

Aims. The aims of the study is to develop a conceptual approach to ensuring the economic security of banking institutions at the state level.

Methods. The following research methods were used to solve this goal: observation and generalization for the development of the Bank's Security Concept; streamlining all key elements of the bank's security concept; a method of scientific generalization that made it possible to formulate conclusions.

Results. In the course of the study, the Bank Security Concept was proposed, which is described in detail and consists of the following elements: general provisions, the purpose and objectives of the bank's security system, principles of organization and functioning of the bank's security system, objects of protection, the main types of risks, threats and security risks of the bank's activities, the legal basis for the organization and operation of the bank's security system, technical security of the bank, managing the bank's security system, proposals for the development of a program for creating a bank security system, principles and directions of the Bank's interaction with law enforcement agencies in the field of security.

This concept allows the bank's manager to determine the basics of the security organization of the credit institution taking into account local conditions and its capabilities for the costs and resources of its provision.

Discussion. In the context of the global financial and economic crisis, the economic security of domestic banks largely depends on the efficiency of their security system. The architecture of a bank's security system must include all internal and external security entities and provide comprehensive protection against all real and potential hazards, threats and risks. To build an effective security system, it is necessary to first of all develop the Bank's Security Concept. This document, based on the analysis of the bank's activities, should specify the goals, objectives and principles of building a reliable protection of the bank against internal and external threats, outline the main directions of creating such a system, give recommendations on the use of innovative technologies, methods and techniques to ensure the security of the bank.

1. General provisions. The concept of bank security is a scientifically grounded system of views on the definition of the main directions, conditions 
and order of practical solution of the tasks of protection of banking from illegal actions and unfair competition.

Bank security means the state of protection of interests of owners, management and clients of the bank, material values and information resources from internal and external threats [1].

Security is an integral part of the business of the bank (credit institution). A state of security is the ability and ability of a credit institution to safely resist any attempt by criminal structures or dishonest competitors to harm the legitimate interests of the bank.

Security objects are:

- staff (management, responsible executors, employees);

- financial resources, tangible assets, the latest technologies;

- information resources (information with restricted access, a component of a trade secret, other confidential information provided in the form of documents and files regardless of the form and type of their presentation).

The subjects of legal relations in solving the security problem are:

- the state (Ukraine), as the owner of the resources created, obtained, and accumulated funds from the state budgets, as well as information resources classified as state secrets;

- the Central Bank of Ukraine, which implements monetary and credit policy of the country;

- commercial bank as a legal entity that owns financial, as well as information resources, which are official, commercial and banking secrecy;

- other legal and natural persons, including partners and clients in financial relations, involved in the process of functioning of the bank both domestically and in external financial relations (public authorities, executive bodies, organizations attracted to provide services in security areas, maintenance staff, customers, etc.);

- bank security services and private security and detective structures.

The concept defines the goals and objectives of the security system, the principles of its organization, operation and legal basis, types of security threats and resources to be protected, as well as the main directions of security system development, including legal, organizational and engineering protection.

2. The purpose and objectives of the bank's security system. The main purpose of the security system is to ensure the stable functioning of the bank and prevent threats to its security, protect the legitimate interests of the credit institution against unlawful encroachments, protect the life and health of staff, prevent theft of financial and logistical means, destruction of property and values, disclosure, loss, leakage, distortion and destruction of official information, impaired operation of technical means, maintenance of production activities, including means of informatization [2].

Other goals of the concept are: 
- formation of a holistic system of bank security and interaction of various elements of this system, determination of ways of implementation of measures that provide the necessary level of reliable security of objects;

- enhancing the image of the bank and increasing profits by providing high quality services and guarantees the security of property rights and interests of clients.

The tasks of the security system are:

- forecasting and timely detection and elimination of security threats to the staff and resources of the bank; causes and conditions that contribute to financial, material and moral damage, disruption of its normal functioning and development;

- classification of information in the category of restricted access (state, official, banking and trade secrets, other confidential information subject to protection against unauthorized use), and other resources - to different levels of vulnerability (danger) and objects of preservation;

- creation of a mechanism and conditions for prompt response to security threats and manifestation of negative tendencies in the functioning of the bank;

- effective elimination of threats to personnel and encroachments on resources through legal, organizational and engineering measures and security measures;

- creation of conditions for the maximum possible compensation and localization of the damage caused to the unlawful actions of individuals and legal entities, mitigating the negative impact of security breaches on the achievement of the strategic goals of the bank.

3. Principles of organization and functioning of the bank's security system. The organization and operation of a security system must comply with the following principles [3]:

1. Complexity:

- ensuring the safety of personnel, material and financial resources against possible threats by all available legal means, methods and measures;

- ensuring the security of information resources throughout their life cycle, at all technological stages of their processing (transformation) and use, in all modes of operation;

- the ability of the system to develop and improve in accordance with changes in the conditions of operation of the bank.

Complexity is achieved:

- ensuring proper regime and protection of the $\mathrm{CB}$;

- organization of special paperwork focusing on the protection of business secrets and bank secrecy;

- recruitment and placement measures;

- widespread use of security and information security;

- detailed information-analytical and detective activities.

Complexity is realized by a set of legal, organizational and engineering measures. 
2. Timeliness is a state of the security system when security measures prevent the implementation of threats.

Timeliness involves setting complex security tasks in the early stages of developing a security system based on the analysis and forecasting of the financial situation, bank security threats, and the development of effective measures to prevent encroachment on legitimate interests.

3. Continuity - Considers that threats and risks are a constant feature of the bank's activities, so the security system must constantly take appropriate measures to counter them.

4. Activity. It is necessary to protect the interests of the bank with a sufficient degree of persistence, widely using maneuver by forces and means of ensuring security and non-standard measures of protection.

5. Legality. It envisages the development of a security system based on the Ukrainian legislation in the field of banking, informatization and protection of information, its security activities and other normative acts on security, approved by public authorities within their competence, using all permitted methods of detection and termination of offenses [4].

6. Justification. The capabilities and remedies used must be implemented at the modern level of development of science and technology, justified from the point of view of a given level of safety and meet the established requirements and standards.

7. The economic feasibility and comparability of the potential loss and cost of security (the criterion "efficiency - cost"). In all cases, the value of the security system must be less than the potential loss from any type of risk.

8. Specialization. It is envisaged to involve in the development and implementation of measures and remedies of specialized organizations, most prepared for a specific type of security activities, with practical experience and a state license for the right to provide services in this field. The operation of technical equipment and the implementation of security measures should be carried out by professionally trained specialists of the Bank's security service, its functional and servicing units.

9. Interaction and coordination. Means the implementation of security measures on the basis of a clear interconnection of relevant units and services, third-party specialized organizations in this field, coordination of their efforts to achieve the set goals, as well as cooperation with interested associations and interaction with public authorities and law enforcement agencies.

10. Improvement. It envisages improvement of measures and remedies based on own experience, emergence of new technical means taking into account changes in methods and means of intelligence and industrial espionage, regulatory and technical requirements, achieved domestic and foreign experience [5].

11. Centralization of management. It assumes the independent functioning of the security system according to the single legal, organizational, functional 
and methodological principles and centralized management of the security system activity.

4. Objects of protection. Objects subject to protection against potential threats and unlawful interference include:

- Bank staff (executives, production staff with direct access to finance, currency, valuables, repositories, knowledge of banking and trade secrets, foreign trade workers, and others;

- financial resources, currency, valuables;

- information resources with limited access, constituting official and trade secrets, as well as other confidential information on paper, magnetic, optical basis, information arrays and databases, software, informative physical fields of various nature;

- information systems and systems, technical means of information transmission, means of reproduction and display of information, auxiliary technical means and systems);

- material means (houses, constructions, storages, technical equipment, transport and other means);

- technical means and systems of protection and protection of material and information resources.

5. The main types of dangers, threats and security risks of the bank. The monitoring, analysis and forecasting of dangerous phenomena in the external and internal environment of the bank indicate that the main real and potential threats to the security of the bank are:

- unstable political, socio-economic situation and aggravation of the criminal situation;

- non-compliance with legal acts, legal nihilism, lack of a number of laws on vital issues;

- reducing the moral, psychological and industrial responsibility of citizens.

At the stage of conceptual consideration of the issue of bank security, it is possible to consider the overall composition of potential threats. Specific listings related to the specifics of the bank and conditions require some detail and are specific to the stage of development of a specific security system project [6].

6. Legal bases of organization and activity of bank security system. The legal bases of bank security are determined by the Constitution of Ukraine, laws and other normative acts.

The existing legal conditions for ensuring bank security generally allow state and non-state security entities to successfully counter illegal attacks on banking security in various aspects.

The security of a particular bank is also achieved by the formation of a system of internal regulations, instructions, regulations, rules, regulations and functional responsibilities of employees of the line units and services, including the security service.

7. Technical security of the bank. Safety assurance should be based on: - on the standardization and unification system; 
- on the system of activity licensing;

- on systems of certification of means of protection;

- on the system of certification of information objects;

- on the system of certification of protected objects by informatization.

The main components of securing the resources of commercial banks are:

- system of physical protection (security) of material objects and financial resources;

- Information resources security system.

8. Management of the bank security system. Legislation and other regulations in force provide for the bank's right to develop its own Security Concept and to implement this concept by creating a security system based on the appropriate security service. Based on the presented in the concept of tasks, principles of organization and functioning of the security system, the main threats to the security of the bank, it is advisable to distinguish the following main areas of activity of the bank to ensure its security:

- information-analytical studies and security estimates, including economic estimates;

- staff safety;

- security and physical protection of financial assets and objects;

- security of information resources.

The main tasks of the area of information-analytical research and safety estimates are:

- obtaining and analyzing information on world and national markets and forecasting their development;

- organization of works on revealing of confidential information, substantiation of the level of its confidentiality and documentation in the form of lists of information to be protected;

- gathering economic and scientific and technical information to ensure the effectiveness of business relations with foreign and domestic partners, identify among them incompetent, unreliable entrepreneurs, as well as persons associated with criminal structures;

- taking into account the official claims of law enforcement and supervisory authorities to possible partners in the financial market, firms, banks, etc .;

- study, analysis and evaluation of the criminal situation, including the state of economic crime in the monetary sphere by country and in the region;

- identification and forecasting of vulnerabilities in monetary activity, real and potential threats to the security of the $\mathrm{CB}$, development and implementation of a set of operational and long-term measures for their prevention and neutralization;

- analysis and forecasting of negative tendencies of socio-economic development of the bank in terms of impact on its security;

- providing information to the bank's management in the field of security;

- Coordinate the activities of security units and ensure interaction with all structural units of commercial banks to address security issues. 
The main concern for the safety of personnel is the protection of the individual against any unlawful interference with his life, material values and personal information [7].

The main tasks of the direction of safety and physical protection of products and objects are:

- establishment of the regime of protection of production objects and objects of vital activity;

- admission and admission regimes;

- providing secure storage of valuables and documents (information carriers), equipping them with modern engineering and technical means of protection;

- organization of physical protection of products in the process of its inhouse transportation;

- control over product safety at all stages of the technological process;

- organization of personal security of a certain category of senior staff and leading specialists from the so-called high-risk group;

- ensuring the interaction of all structures involved in providing physical protection.

The main tasks of the direction of information resources security are:

- organization and implementation of the permitting system for the admission of contractors to work with documents and information of restricted access;

- organization of storage and circulation of confidential documents (media);

- private correspondence and encrypted communication;

- organization and coordination of work on information security, processed and transmitted by means and systems of computers and communication;

- security in the course of confidential meetings, negotiations;

- control over the security of confidential documents (storage media), ensuring the protection of information processed and transmitted by means and systems of computers and communications.

The main tasks in working with the bank staff are:

- Recruitment: create a pool of potential candidates in all positions. Recruitment is usually done from internal (relocation and promotion of its employees) and external sources. The main requirement in this case should be an objective assessment not only of the employee for the employee, but also the job offered to him.

- Selection of candidates. The main groups of qualities for comparison of candidates include: professional, educational, organizational and personal. The main requirement in the selection process is to carefully study the business, moral and ethical data of each candidate through a thorough study of the candidate's working past. In the process of analyzing information about the candidate, the services of law enforcement agencies provided by them in accordance with the current legislation of Ukraine should be used. 
- The conclusion of the contract and the voluntary consent of the employee to comply with the requirements governing the security regime and the preservation of commercial and banking secrets.

- Training candidates prior to admission to employment involves the appointment, training of the established rule of execution of the task, ensuring security and protection of information.

- Current monitoring (monitoring) of the employee's activity to increase his / her vigilance regarding bank security threats.

- Timely identification and elimination of conflict situations in work with personnel.

Given the territorial dispersion and the different nature of the activities of the structural units of the bank, the need to have a large part of their security services, as well as the availability of national regulations governing the protection of objects, products and transportation of products, it seems impossible at this time to organize a single service security of the bank with centralized administrative subordination [8].

In these circumstances it is advisable to create a territorially distributed security service with centralized organizational and methodological support, centralized management and coordination of activities according to uniform principles and rules.

The security service must submit directly to the head of the bank. It is advisable to allow the head of the security service to be in the rank of deputy head of the bank, which would administratively manage the service of analytical and security assessments, security units and physical protection of values and other objects of the bank, ensuring the security of information resources, and it also coordinated the actions of all the Bank's structural units to prevent hazards, threats and risks to the Bank's operations.

Issues of technical security in the areas of activity of the security service should be solved together with the management and units responsible for the direction of scientific and technological development.

During the development and implementation of the security system and the organization of its security service, a certain part of the security service personnel may be engaged to perform specific works (consultations) on a contractual basis (on a contractual basis) from among an appropriate profile of highly qualified specialists.

9. Proposals for the development of a program for creating a bank security system. In general, the following documents should be developed in order to create and maintain the Bank's integrated security system, taking into account the provisions of this concept:

- Charter (provision) of the security service.

- A list of trade secret information.

Organizational and administrative documents regulating the procedure and rules:

- Secrecy of trade secrets; 
- the mode and protection of security objects, including requirements for bandwidth and intra-object mode;

- accounting and control of finances, ensuring their safety in the process of operations, storage and transportation;

- ensure the protection of information processed and transmitted by automated systems and communications.

For implementation of technical policy in the field of providing physical and information protection it is necessary to develop and implement a set of measures:

- to equip the most important facilities and facilities with the means and systems of physical protection and control;

- providing technical, software and cryptographic protection of information in information and communication systems;

- to ensure the protection of linguistic information in premises designated for confidential negotiations.

The program of creation of the security system should stipulate the priorities of realization of the most important and urgent directions of ensuring of security, taking into account the allocated financial resources, as well as involve involvement in its execution of specialized organizations having practical experience in dealing with the problem and licenses for the respective type of activity [9].

10. Principles and directions of the bank's interaction with law enforcement agencies in the field of security. Whatever the self-organization of the security of the bank, it will not ensure the prevention of criminal encroachment without the interaction of the credit institution with the relevant law enforcement agencies and, above all, the police.

The legal basis for such interaction is: constitutional principles of equality of protection of all forms of property; the laws of Ukraine on the police, on the operative-search activity, on the prosecutor's office and other legal acts; Agreements between the Ministry of Internal Affairs of Ukraine and banks on cooperation in the field of banking security [10].

The goals of the cooperation are: prevention and disclosure of criminal attacks on personnel, funds and values. Priority areas for cooperation between the bank and the territorial interior should be:

1) Information exchange:

- facts (ways) of theft of funds in commercial banks using counterfeit bank documents, credit cards, forgery of other documents;

- individuals working in commercial banks, depositors and other clients suspected of committing offenses;

- legal entities that are customers of the bank, the banking operations they do have a suspicious nature, in general, about banking transactions that raise reasonable doubts about the expediency of their conduct.

2) Development of joint activities: 
- counteracting the alleged (real) facts of generally punishable manifestations in the banking system, the threat of murder, or grievous bodily harm, the destruction of property of commercial banks, their managers, employees and their families;

- on technical security and equipment by means of signaling of objects of the bank;

- the creation of a so-called "hot line" between the banking and territorial police (police);

- participation in the formation of a centralized, regional data bank on enterprises of different ownership forms, dishonest participants in credit and monetary relations.

3) Recruitment, placement and professional training of bank security services:

- Carrying out joint screening of bank security applications using the information capabilities of law enforcement agencies, criminal records, etc.;

- joint development and introduction of rules on the liability of commercial bank staff for unlawful use or disclosure of commercial (banking) secrets ";

- use of police assistance in training and refresher training of the bank's security services.

Thus, this concept allows the bank's manager to determine the basics of the security organization of the credit institution taking into account local conditions and its capabilities for the costs and resources of its provision.

Conclusion. Public authorities and banks and citizens should be interested in: maintaining a stable legal system, protecting the rights declared by law; its financial security; ensuring the stability of the currency, other macroeconomic conditions that dictate the shape of their own individual reproduction. Such legal environment consists of: the main structural components of the economic and financial system: monetary unit, banking architecture, currency regime, tax system, financial system, commodity markets, capital, labor, derivatives, market infrastructure, customs system, etc.; regulatory framework that regulates: financial, banking, security, currency, foreign economic, budgetary, credit, economic, etc. processes in the country; systems of capable state institutions that ensure compliance with the provisions of this regulatory framework and systems of institutions that ensure the functioning of markets that serve flows of capital, goods, money and information; systems of civil institutions, which are the foundations of a market-based economic system: respect for the law, respect for property rights, business ethics, etc.

The conducted research has shown that the factors of the bank are seriously influenced by the factors of the internal environment: the level of training and reliability of the personnel, the general organization of activity, the intensity of the introduction of modern banking technologies, protection of trade secrets and more. The stated aim of ensuring the economic security of banks is achievable only in its systematic implementation. 


\section{References:}

1. Zarytska, I. (2009), "Background and features of the current global banking crisis", Visnyk NBU, № 6, pp. 21-29.

2. Koval, Ya. (2019), "Bankivski innovatsii yak neobkhidnist efektyvnoho funktsionuvannia derzhavnoho mekhanizmu", ${ }^{\prime} O H O \Sigma$. Mystetstvo naukovoi dumky, №6, pp. 15-20. DOI: 10.36074/2617-7064.06.00.003.

3. Zachosova, N. V. (2019), "Modeling of the mechanism of managing the financial and economic security of professional financial market participants, taking into account the state influence on this process", Naukovi zapysky Natsionalnoho universytetu "Ostrozka akademiia». Seriia «Ekonomika», vol. 12 (40), pp. 101-105.

4. Koval, Ya. Mihus, I. Haman, P. and Andriyenko, M. (2019), "The state of economic security of Ukrainian banking institutions and the effect of economic reforms on formation of anti-crisis measures", Financial credit activity: problems of theory and practice, №2 (29), pp. 32-43.

5. Suhoniako, O. (2006), "National Banking System and Foreign Capital Expansion: Finding Measure", Visnyk NBU, pp. 27-32.

6. Koval, Ya. (2018), "Stress-testing of complex risks in the banking system, as an instrument of state anti-crisis management”, Public management, №2. pp. 124-135. DOI : https://doi.org/10.31618/vadnd.v1i12.87.

7. Prymostka, L. O. Lysenok, O. V. and Chub, O. O. (2008), Bankivski ryzyky: teoriia ta praktyka upravlinnia [Banking risks: management theory and practice], KNEU, Kyiv, Ukraine, 456 p.

8. Bukyn, S. (2003), "Bank security", Bankovskye tekhnolohyy, № 9. URL : www.bizcom.ru/security/2003-09/01.html.

9. Hrytsenko, R. (2003), "Economic security of the banking system of Ukraine", Visnyk Natsionalnoho banku Ukrainy, № 4, pp. 27-28.

10.Baranovskyi, O. I. (2004), Finansova bezpeka v Ukraini [Financial security in Ukraine], Kyiv National University of Trade and Economics, Kyiv, Ukraine, 759 p.

Received: January 20, 2020 